\title{
SEBUTAN JOHOR-RIAU DAN SEBUTAN BAKU DALAM KONTEKS IDENTITI MASYARAKAT MELAYU SINGAPURA
}

\author{
Mukhlis Abu BAKAR \\ National Institute of Education, Singapore \\ mukhlis.abubakar@nie.edu.sg
}

Manuscript received 29 May 2019

Manuscript accepted 21 Oct 2019

*Corresponding author

10.33736/ils.1521.2019

\begin{abstract}
ABSTRAK
Penubuhan Radio Malaya pada tahun 1946 di Singapura merupakan titik penting dalam perkembangan Sebutan Johor-Riau (SJR) sebagai sebutan standard bahasa Melayu di Malaysia dan Singapura. Pada tahun 1993, selaras dengan usaha pembakuan sebutan bahasa Melayu di Nusantara, pemerintah Singapura mengisytiharkan Sebutan Baku (SB) sebagai sebutan standard, menggantikan SJR, untuk digunakan di sekolah-sekolah, stesen-stesen penyiaran dan di upacara rasmi. Tidak seperti Malaysia yang kembali kepada SJR pada tahun 2000, Singapura mengekalkan SB. Makalah ini menyorot evolusi sebutan standard bahasa Melayu dalam konteks sosio-sejarah orang Melayu Singapura dan Malaysia dan turut menilai semula kebakuan SB. Lima gagasan penting telah dikenal pasti: 1) SJR (atau kelainan /ə/) dan kelainan /a/ merupakan dua model sebutan standard bahasa Melayu yang tumbuh secara tabii (SJR di selatan Semenanjung dan kelainan /a/ di utara); 2) Peristiwa-peristiwa penting yang berlaku secara kebetulan dalam jaringan ketersebaran SJR menjadikannya sebutan standard yang lebih berpengaruh daripada kelainan /a/; 3) Identiti bahasa orang Melayu Singapura terkait rapat dengan SJR. 4) SB adalah model sebutan yang dibuat-buat berpandukan prinsip 'sebut sebagaimana dieja' dan tidak dapat dipakai untuk bahasa Melayu selagi ejaan tidak menepati sebutan; 5) SB yang dituturkan di Singapura muncul sebagai sebutan hibrid campuran SB dan SJR. Makalah ini turut membincangkan implikasi daripada penerusan dasar SB di Singapura.
\end{abstract}

Kata kunci: Sebutan Baku, Sebutan Johor-Riau, Bahasa Melayu Standard; Identiti bahasa 


\title{
SEBUTAN JOHOR-RIAU AND SEBUTAN BAKU IN THE CONTEXT OF THE SINGAPORE MALAY IDENTITY
}

\begin{abstract}
The establishment of Radio Malaya in 1946 in Singapore was an important milestone in the development of Sebutan Johor-Riau (SJR) as the standard pronunciation in Malay in Malaysia and Singapore. In 1993, in line with efforts to standardise Malay pronunciation in the archipelago, the Singapore government introduced Sebutan Baku (SB) as the standard pronunciation, replacing SJR, for use in schools, broadcasting stations and during official ceremonies. Unlike Malaysia, which returned to $S J R$ in 2000, Singapore retained SB. This paper reviews the literature on standard pronunciation in Malay in the context of the socio-history of the Malays in Singapore and Malaysia and re-evaluates $S B$ as a standard pronunciation. The following points emerged: 1) SJR (or /a/ variety) and /a/ variety are two models of standard pronunciation in Malay that evolved naturally (SJR in the south, and the /a/ variety in the north, of the Malay Peninsula); 2) significant events that occurred within SJR's distributed network made it a standard pronunciation that is more influential than the /a/ variety; 3) the Singapore Malay language identity is closely related to SJR. 4) SB is a created model of pronunciation based on the principle 'words are pronounced as they are spelled' and cannot be applied to Malay for as long as the words are not spelled as they are pronunced; 5) SB as spoken in Singapore emerges as a hybrid - a mix of SB and SJR. This paper also discusses the implications from the continuation of the SB policy in Singapore.
\end{abstract}

Keywords: Sebutan Baku, Sebutan Johor-Riau, Standard Malay; Language Identity

\section{Pengenalan}

Pada tahun 1993, selaras dengan usaha penyeragaman bahasa Melayu antara Indonesia, Malaysia dan Singapura yang bermula sejak tahun 50-an, pemerintah Singapura mengangkat Sebutan Baku sebagai sebutan yang standard atau baku menggantikan sebutan standard yang sedia ada pada waktu itu, iaitu sebutan berasaskan loghat Johor-Riau (Asmah Haji Omar, 1988; 1992a). Sebutan Baku diperkenalkan di sekolah-sekolah dan di stesen-stesen penyiaran dan turut disyorkan penggunaannya di acara-acara rasmi yang berbahasa Melayu (CPDD, 1990). Sepanjang pelaksanaan Sebutan Baku, banyak tengkarah yang timbul dalam kalangan masyarakat dengan ada yang menyokong dasar tersebut dan ada yang tidak (BH, 2011a; BM, 2018; ST, 2013). Kini, lebih 25 tahun kanak-kanak Melayu di Singapura terdidik dengan Sebutan Baku bagi mata pelajaran bahasa Melayu di sekolah. Masyarakat umum juga disajikan dengan berita di radio dan di televisyen yang disampaikan menggunakan Sebutan Baku.

Banyak yang telah ditulis mengenai Sebutan Baku, antaranya oleh Asmah (1992b), Asraf (1984), Awang Sariyan (2000), Mohamed Pitchay Gani (2004) dan Suratman Markasan (1989). Rata-rata, semua sarjana ini kecuali Asmah (1992b) 
memberi sokongan penuh kepada dasar Sebutan Baku. Awang (2000) malah menganggap mereka yang menolak Sebutan Baku sebagai kumpulan yang kurang faham akan konsep pembakuan bahasa termasuk sistem sebutan. Makalah ini bertujuan untuk menyumbang kepada wacana tentang Sebutan Baku dengan meneliti konsep sebutan baku itu sendiri sambil menyorot sejarah perkembangan bahasa Melayu standard serta keterikatan sebutan yang berasaskan Johor-Riau dengan identiti bahasa orang Melayu Singapura. Makalah ini turut membincangkan implikasi daripada penerusan dasar Sebutan Baku.

\section{Bahasa Melayu di Nusantara}

Bahasa Melayu adalah bahasa asli di Singapura dan kawasan-kawasan di sekelilingnya termasuk Semenanjung Malaysia dan selatan Thailand, bahagian tengah dan timur Sumatera, Kepulauan Riau hinggalah ke pantai barat pulau Borneo (Asmah, 2005). Di luar kawasan teras ini - dari Sumatra ke Papua Barat - kawasan yang diberi nama Nusantara atau Kepulauan Melayu - bahasa Melayu merupakan lingua franca dalam kalangan komuniti-komuniti yang mempunyai bahasa asli mereka sendiri. Bahasa Melayu juga berfungsi sebagai bahasa perdagangan dan bahasa perhubungan antara kerajaan. Hal ini disebabkan oleh pengaruh kerajaankerajaan Melayu pada waktu dahulu, bermula dengan Kerajaan Srivijaya di Palembang, Sumatra, dari abad ke-7 dan kemudian kesultanan Melaka dari abad ke15 (Collins, 1998).

Kejatuhan Kesultanan Melaka kepada Portugis pada tahun 1511 diikuti dengan kemunculan kesultanan-kesultanan lain di kawasan asli Melayu termasuk kesultanan Johor-Riau (abad ke-17 hingga ke-19). Dialek Johor-Riau menjadi dialek tempatan di wilayah-wilayah kesultanan Johor-Riau. Kawasan dialek ini mencakupi daerahdaerah di Sumatra timur termasuk Kepulauan Riau, Singapura, Johor, Pahang dan Selangor. Dialek ini juga mempunyai banyak persamaan dengan dialek yang penyebarannya sampai ke Ipoh di Perak (Asmah, 1992a).

Dunia Melayu terbahagi secara politik buat kali pertama dalam sejarahnya pada tahun 1824 dengan Perjanjian British-Belanda. Di bawah perjanjian itu, Britain menguasai Singapura dan Semenanjung Tanah Melayu serta sepertiga Borneo (kini Malaysia) manakala Belanda menguasai kawasan selebihnya (kini Indonesia). Di kawasan-kawasan yang dikuasai Belanda, penutur asli bahasa Melayu membentuk kumpulan minoriti di samping penutur asli ratusan bahasa lain termasuk bahasa Jawa yang amat berpengaruh. Maka berputiklah kelainan bahasa Melayu di wilayah Belanda yang berpusat di Jawa yang menerima pengaruh pelbagai bahasa khususnya bahasa Belanda dan Jawa selain bahasa-bahasa asli yang lain. Kelainan ini kian berbeza daripada bahasa Melayu yang dituturkan di kawasan teras Melayu, khususnya Singapura dan Semenanjung Tanah Melayu (Alisjahbana, 1976; Asmah, 1993; Collins, 1998). Menjelang kemerdekaan Indonesia, kelainan ini diisytiharkan sebagai bahasa kebangsaan Indonesia dan dinamakan Bahasa Indonesia. 


\section{Dialek Johor-Riau dalam Pembentukan Bahasa Melayu Standard}

Bahasa Melayu di Singapura dan Malaysia berkembang secara bersama untuk tempoh yang agak lama. Kedua-dua negara mengongsi sejarah penjajahan yang sama. Selain itu, negeri Johor dan Singapura terletak dalam daerah dialek Melayu yang sama, iaitu dialek Johor-Riau (Asmah, 1988; Winstedt, 1992). Menurut para sarjana bahasa (Asmah, 1988; Asraf, 1984), dialek inilah yang menjadi asas kepada Bahasa Melayu Standard yang digunakan di kedua-dua buah negara walaupun terdapat beberapa dialek Melayu yang lain di semenanjung Tanah Melayu. Hal ini demikian kerana Singapura yang berdialek-kan Johor-Riau merupakan pusat budaya, politik dan sosio-ekonomi masyarakat Melayu yang mencapai kemuncaknya pada zaman penjajahan British (Asmah, 1992a; Heng, 2011).

Akhbar bahasa Melayu di Malaya bermula di Singapura pada akhir abad ke19. Dengan tertubuhnya media percetakan, nahu dan kosa kata dialek Johor-Riau 'dipinjam' untuk percetakan. Norma-norma yang dibangunkan untuk bahasa tulisan yang dipelopori golongan inteligensia, yang pada awalnya menggunakan skrip Jawi (Amat Juhari Moain, 1996; Hashim Musa, 2006), tersebar ke sekolah-sekolah, institusi perguruan dan pejabat-pejabat kerajaan di seluruh Malaya dan Singapura. Proses pengintelektualan bahasa berterusan hingga terbentuk kelainan bahasa Melayu yang supralokal, iaitu tidak dibatasi kawasan. Kelainan ini dikenali sebagai Bahasa Melayu Standard (BMS) (Asmah, 1988).

Perkhidmatan radio pula mula beroperasi pada tahun 1946 dengan tertubuhnya Radio Malaya di Singapura. Jika dialek Johor-Riau menjadi model bagi bahasa bercetak (Asraf, 1984), sebutan dialek Johor-Riau pula menjadi norma sebutan juruhebah dan pembaca berita yang bertugas di stesen radio (Asmah 1988, 1992a). Seperti yang berlaku kepada nahu dan kosa kata dialek Johor-Riau, sebutan dialek itu juga berkembang bagi memenuhi fungsinya yang meluas sambil menampung penyebutan perkataan-perkataan baharu yang dipinjam daripada bahasa lain. Gaya sebutan ini dibawa ke Kuala Lumpur apabila Radio Malaya berpindah ke sana dan ke utara apabila Pulau Pinang membuka stesen radionya sendiri, juga di Sabah dan Sarawak (Asmah, 1992a). Maka lahirlah sebutan standard bahasa Melayu supralokal yang merupakan variasi kepada sebutan asal dialek JohorRiau. Makalah ini menamakan sebutan standard ini Sebutan Johor-Riau (SJR), mengekalkan nama 'Johor-Riau' bagi mengiktiraf asal-usulnya. Asmah (1992a) merujuknya sebagai kelainan /ə/ atau kelainan 'pepet'.

Jelas bahawa pemilihan dialek Johor-Riau sebagai asas kepada pembentukan BMS dan SJR berlaku secara kebetulan dan bukan kerana perancangan atau ketetapan yang dibuat oleh pihak berkuasa (Asmah, 1992a). Laluan yang ditempohi bahasa Melayu standard ini, daripada sebuah dialek kawasan kepada dialek sosial yang diterima masyarakat tanpa dipaksa, tidak unik kepada bahasa Melayu sebaliknya mengongsi sejarah yang serupa dengan bahasa-bahasa dunia yang lain seperti bahasa Inggeris (Coupland, 2014; Hjarvard, 2004).

Harus diingat bahawa sebutan standard bahasa Melayu adalah dwipusat (Asmah, 1992b). Selain daripada SJR (atau kelainan /ə/), terdapat juga kelainan /a/ yang dituturkan di utara Semenanjung Malaysia dan Sabah dan Sarawak. Antara dua sebutan yang tabii ini, SJR memainkan peranan penting sebagai model sebutan di 
stesen-stesen penyiaran. Oleh yang demikian, ia sebutan yang lebih berpengaruh daripada kelainan /a/. Penutur kelainan /a/ boleh didengar beralih antara keduadua kelainan dalam peristiwa-peristiwa bahasa tertentu manakala dalam kalangan penutur SJR, mereka terbiasa dengan kelainan /a/ hanya dalam nyanyian dan deklamasi sajak (Asmah, 1992b). Di samping itu, kelainan /a/ sering disalah anggap sebagai Sebutan Baku kerana beberapa ciri yang dikongsi bersama. Hal ini dijelaskan dalam bahagian tentang ciri-ciri Sebutan Baku.

\section{Bahasa Melayu di Singapura}

Apabila Singapura berpisah daripada Malaysia pada tahun 1965, ia mewarisi BMS, baik dalam bentuk tulisan mahupun lisan. BMS adalah salah satu daripada dua dialek sosial bahasa Melayu yang dituturkan di Singapura. Dialek sosial yang satu lagi ialah Bahasa Melayu Basahan (BMB) yang juga terbit daripada dialek Johor-Riau (Asmah, 1986). ${ }^{1}$ BMS bercirikan sistem penggabungan yang kompleks, iaitu penambahan imbuhan pada kata akar ('me-'+'tolak' $\rightarrow$ 'menolak', 'ber-'+'lari' $\rightarrow$ 'berlari'), ciri yang sering digugurkan dalam BMB (Benjamin, 1993; Koh, 1990). Dalam BMB, katakata kerap dipendekkan (contohnya, 'tidak' /tida?/ $\rightarrow$ /ta?/, 'hendak' /hənda?/ $\rightarrow$ /na?/; /h/ antara dua vokal digugurkan (misalnya, 'mahu' /mahu/ $\rightarrow$ /mau/, 'tahu' /tahu/ $\rightarrow$ /tau/); dan penambahan hentian glotis (/ $/$ /) untuk perkataan yang berakhir dengan 'i' dan 'a' (misalnya, 'nasi' /nasi/ $\rightarrow$ /nasi?/, 'bawa' /bawə/ $\rightarrow$ 'bawak' /bawa?/). ${ }^{2}$

Sementara BMS ialah dialek formal yang digunakan oleh golongan terdidik di institusi pendidikan, media dan di upacara rasmi, BMB pula ialah dialek yang tidak tertulis, digunakan sebagai bahasa basahan di rumah dan dalam pelbagai situasi yang tidak rasmi (Koh, 1990). Kedua-dua BMS dan BMB, bagaimanapun, berkongsi ciri sebutan yang sama, iaitu SJR. Sama ada seorang penutur mengucapkan 'tidak cukup' (bentuk BMS) atau 'tak cukup' (bentuk BMB), 'cukup' disebut dengan cara yang sama (/tfukop/). Begitu juga dengan suku kata 'pa' dalam 'tidak apa' (BMS) dan 'takpa' (BMB); ia disebut dengan cara yang sama (/tida? apə/ dan /ta?pə/). Jelas di sini bahawa identiti orang Melayu Singapura dari segi bahasanya berkait rapat dengan SJR.

\section{Usaha Penyeragaman Bahasa Melayu di Nusantara}

Perbezaan yang semakin ketara antara bahasa Indonesia dan bahasa Melayu di negara-negara lain di Nusantara mendorong para bahasawan dari Malaya, Singapura dan Indonesia pada tahun 50-an untuk memulakan usaha menghasilkan satu bahasa Melayu yang standard untuk rantau ini (Muhd Ariff Ahmad, 1993). Ini melibatkan pengkodifikasian bahasa dengan lebih tersusun bermula dengan ejaan diikuti dengan peristilahan, tatabahasa, perkamusan dan akhirnya sebutan. Bagaimanapun, keseragaman penuh merentas sempadan politik sukar dicapai, terutama sebutan (Milroy \& Milroy, 2012). 
Ada beberapa faktor yang menghambat penyeragaman. Pertama pengaruh luar. Ejaan dan penerbitan kata perkataan dan imbuhan asing yang dipinjam ke dalam bahasa Indonesia dipengaruhi bahasa Belanda manakala Bahasa Melayu di Malaysia dan Singapura dipengaruhi bahasa Inggeris. Bagaimanapun, dalam arena kebahasaan Indonesia masa kini, lebih banyak kata bahasa Inggeris diindonesiakan berbeza dengan kebahasaan Melayu yang lebih cenderung mengekalkan kata bahasa Melayu yang ada. Kedua pengaruh dalaman: Bahasa Indonesia bahasa penyatu pelbagai penutur bahasa asli yang terdapat di Indonesia yang mempengaruhi kosa kata Bahasa Indonesia; Bahasa Melayu pula berinteraksi dengan dialek-dialek bahasa yang sama. Ketiga hubungan terhad di antara penutur: siaran radio dan televisyen di kedua-dua negara jarang melintasi sempadan politik, begitu juga bahan-bahan bercetak yang diterbitkan di kedua-dua negara. Keempat rasa bangga dan pemeliharaan identiti: Bahasa Indonesia dan Bahasa Melayu adalah penanda identiti bagi penutur masing-masing yang lebih cenderung untuk mengekalkan bahasa mereka sendiri (Asmah, 1992a, 1993). Hingga hari ini, Bahasa Indonesia terus berkembang mengikut arah yang tersendiri yang berlainan daripada Bahasa Melayu di Malaysia dan Singapura. Baru-baru ini terbit sebuah kamus bahasa Indonesia-bahasa Melayu bagi memudahkan para penutur kedua-dua bahasa memahami perbezaan antara bahasa mereka (Rusdi Abdullah, 2016).

Pada tahun 1993, selaras dengan harapan awal terhadap usaha penyeragaman bahasa Melayu di Nusantara, pemerintah Singapura, atas nasihat Majlis Bahasa Melayu Singapura (MBMS) mengisytiharkan Sebutan Baku (SB) sebagai sebutan yang baku, menggantikan SJR, untuk diamalkan di sekolah-sekolah, stesen-stesen media dan untuk kegunaan di upacara rasmi (Muhd Ariff, 1993). Ini menyusuli perisytiharan yang serupa yang dibuat oleh kerajaan Malaysia lima tahun sebelum itu pada tahun 1988. Bagaimanapun, pada tahun 2000, setelah 12 tahun melaksanakan SB, kerajaan Malaysia memansuhkannya dan kembali kepada 'sebutan biasa' (iaitu kelainan /ə/ atau SJR) kerana bimbang akan terhakisnya identiti orang Melayu yang sekian lama berteraskan 'sebutan biasa' itu (Utusan Online, 2000a). ${ }^{3}$ Singapura, bagaimanapun, kekal dengan dasar SB hingga hari ini. Pengekalan SB di Singapura, bagaimanapun, mengundang banyak tengkarah $(\mathrm{BH}$, 2011a; BM, 2018).

Berbeza dengan sebutan standard kelainan /ə/ (SJR) dan kelainan /a/ yang masing-masing mempunyai sistem fonologinya yang tersendiri kerana tumbuh dan berkembang secara tabii dalam masyarakat penuturnya di Malaysia dan Singapura, SB ialah fenomena baru bagi penutur di kedua-dua negara ini, model sebutan yang dibuat-buat yang berpandukan prinsip 'sebut sebagaimana yang dieja' (Asraf, 1984; Dahaman, 1994; Mohamed Pitchay Gani, 2004; Suratman, 1989) yang dipaksa ke atas penutur bahasa Melayu. Model sebutan ini dinamakan 'Sebutan Baku' dengan meletakkan kata 'baku' di dalam namanya tetapi ini tidak dengan sendirinya menjadikannya sebutan yang baku.

\section{Ciri-ciri Sebutan Baku}

SB menuntut penuturnya mengucapkan perkataan mengikut cara perkataan itu dieja. la mengandaikan bahawa satu huruf dapat dipadankan dengan satu bunyi, dan 
semua huruf yang muncul dalam perkataan mesti diucapkan (Ismail, 1994). Berdasarkan panduan ini, SB berbeza dengan SJR atas tiga ciri utama berkaitan dengan posisi huruf dalam unit kata: 1) huruf 'a' di suku kata akhir terbuka disebut /ə/ dalam SJR tetapi /a/ dalam SB; 2) huruf ' $i$ ' dan ' $u$ ' di suku kata akhir tertutup masing-masing disebut /e/ dan

Jadual 1

Ciri-ciri utama beberapa sebutan standard bahasa Melayu

\begin{tabular}{|c|c|c|c|c|}
\hline $\begin{array}{ll}\text { Posisi bunyi } \\
\text { dalam kata }\end{array}$ & $\begin{array}{c}\text { Sebutan } \\
\text { Johor-Riau } \\
\text { (kelainan /ə/) }\end{array}$ & $\begin{array}{c}\text { Sebutan } \\
\text { Utara }^{4} \\
\text { (kelainan /a/) }\end{array}$ & $\begin{array}{c}\text { Sebutan } \\
\text { Baku }\end{array}$ & $\begin{array}{c}\text { Sebutan } \\
\text { Bahasa } \\
\text { Indonesia }\end{array}$ \\
\hline 1. 'a' di suku kata akhir terbuka & /ə/ & /a/ & /a/ & /a/ \\
\hline $\begin{array}{l}\text { 2. 'i' \& 'u' di suku kata akhir } \\
\text { tertutup } \\
\text { a. sebelum, 'n', 'ng'; } \\
\text { b. sebelum konsonan lain }\end{array}$ & $\begin{array}{l}\text { /e/ \& /o/ } \\
\text { /e/ \&/o/ }\end{array}$ & $\begin{array}{l}\text { /i/ \& /u/ } \\
\text { /e/ \& /o/ }\end{array}$ & $\begin{array}{l}\text { /i/ \& /u/ } \\
/ \mathrm{i} / \& / \mathrm{u} /\end{array}$ & $\begin{array}{l}\text { /i/ \& /u/ } \\
/ \mathrm{i} / \& / \mathrm{u} /\end{array}$ \\
\hline 3. 'r' di akhir suku kata & senyap & $/ r /$ & $/ r /$ & $/ r /$ \\
\hline
\end{tabular}

/o/ dalam SJR tetapi /i/ dan /u/ dalam SB; dan 3) huruf ' $r$ ' di akhir suku kata disenyapkan dalam SJR tetapi dibunyikan dalam SB. Perbezaan ini ditunjukkan dalam Jadual 1 yang turut menyenaraikan pola sebutan kelainan /a/ dan sebutan Bahasa Indonesia.

Berdasarkan tiga ciri ini, SB serupa dengan sebutan bahasa Indonesia. Sebaliknya, SJR berbeza daripada kedua-duanya. Oleh itu, meminta penutur bahasa Melayu dari Singapura dan Malaysia bercakap menggunakan SB seakan meminta mereka bercakap seperti orang Indonesia ${ }^{5}$ (misalnya, /lupa/, bukan /lupə/; /sakit/, bukan /saket/; /takut/, bukan /takot/; /tukar/, bukan /tuka/). Bayangkan situasi yang mana penutur asli bahasa Inggeris dari Britain dianjurkan supaya melucutkan cara sebutan mereka (misalnya, /ka:/ ('car') dan /a:sk/ ('ask')) dan bercakap seperti penutur bahasa Inggeris Amerika (/ka:r/ ('car') dan /æsk/ ('ask')). Pastinya mereka tidak akan menyambut baik anjuran tersebut kerana ini bermakna meminggirkan identiti mereka sebagai orang British, yang antara-nya diindekskan melalui sebutan. Hal ini demikian kerana sebutan ialah indikator penting identiti bahasa (Lippi-Green 1997). Atas alasan yang sama, dapat difahami mengapa Malaysia memansuhkan dasar SB (Utusan Online, 2000a).

\section{Ketakwajaran Sebutan Baku}

Bagi menyokong SB, Asraf (1984) memetik pernyataan K. L. Pike dalam bukunya berjudul Phonemics: "kata-kata dieja sebagaimana yang diucapkan dan diucapkan sebagaimana yang dieja, dan tidak ada huruf yang senyap" (Pike, 1947: 57). Pernyataan ini didahului dengan penjelasan tentang bagaimana setiap bunyi bahasa (atau fonem) wujud dengan pelbagai variasi bunyi (atau alofon). Sebagai contoh, 
bunyi / $\mathrm{t}$ / yang diwakili huruf ' $\mathrm{t}$ ' disebut dengan bibir hampar dalam 'tilam' [tilam] tetapi dengan bibir bundar dalam 'tulang' [ ${ }^{\mathrm{w}} \mathrm{ula \eta}$ ]; huruf 'a' yang pertama dalam [mãlas] disebut dengan bunyi sengau tetapi yang kedua tanpa sengauan. Jika dinilai secara akustik, bunyi-bunyi ini berbeza. Namun demikian, penutur asli tidak akan mendengar perbezaan ini, mendengarnya hanya sebagai satu bunyi ' $t$ ' dan satu bunyi ' $a$ ', iaitu mengenali bunyi bahasa di peringkat fonem. Atas pertimbangan ini, Pike berpendapat bahawa sistem ejaan yang praktikal adalah sistem yang memperuntukkan satu huruf bagi satu fonem.

Perhatikan bahawa Pike (1947) mengutamakan bunyi (fonem) daripada huruf kerana huruf hanya perwakilan bunyi bahasa. Hanya apabila sistem ejaan itu benarbenar fonemik, iaitu satu huruf dipadankan dengan satu bunyi, iaitu dieja sebagaimana yang diucapkan, barulah kata-kata dapat diucapkan sebagaimana yang dieja. Bagi bahasa Melayu, walaupun sistem ejaannya lebih fonemik daripada kebanyakan bahasa, ia masih tidak fonemik sepenuhnya. Sebagai contoh, bunyi /e/ (dalam 'enak') dan /ə/ (dalam 'emas') tidak ada padanan huruf yang tersendiri; kedua-duanya dieja 'e'. Begitu juga bunyi /k/ dan /?/ (dalam 'kakak' /kaka?/, keduadua bunyi ini diwakili huruf yang sama, iaitu ' $k$ '. Seterusnya, ejaan bagi akhiran 'an' juga tidak fonemik kerana tidak mewakili dengan tepat kepelbagaian sebutan bagi akhiran ini (misalnya, /wan/ dalam 'tiru-an'; /jan/ dalam 'tepi-an'; / Pan/ dalam 'duga-an'; dan /an/ dalam 'kasih-an') (Asmah, 2008; Farid M. Onn, 1980).

Banyak lagi ketidsepadanan antara huruf dengan bunyi yang hanya dapat ditemukan melalui analisis fonologi bahasa Melayu (Farid, 1980). Kesemua ini menunjukkan bahawa sistem ejaan bahasa Melayu yang sedia ada tidak memenuhi tuntutan sistem ejaan yang fonemik. Jika ejaan tidak mewakili sebutan dengan tepat, maka sebutan tidak boleh berpandukan ejaan (Pike, 1947). SB, yang berdiri atas dasar 'sebut sebagaimana yang dieja', tidak dapat dipakai untuk bahasa Melayu. Selain itu, ia juga mengelirukan. Terdapat perkataan seperti 'baka' (benih) yang disebut /bakə/ dalam SJR tetapi tidak lagi dapat dikenali jika disebut /baka/ seperti yang dituntut dalam SB.

\section{Pendorong Sebutan Baku}

Apakah yang mendorong pemerintah Singapura mengekalkan SB di Singapura? Dua motivasi dapat dikenal pasti (BH, 2004; BM, 2018):

\section{Sebutan Baku lebih 'sistematik dan konsisten' daripada Sebutan Johor-Riau}

Penyokong SB menganggap SB lebih 'sistematik dan konsisten' daripada SJR. SJR dikatakan membenarkan banyak perkecualian yang menyimpang daripada rumus deskriptif yang ada (Asraf, 1984; Suratman, 1989). Sebagai contoh, rumus fonologi yang mengubah /a/ di akhir kata kepada /ə/ beroperasi untuk perkataan seperti 'suka' (/sukə/) dan 'bahasa' (/bahasə/) tetapi tidak untuk 'bola' (/bola/) dan 'wanita' (/wanita/). Begitu juga dengan rumus fonologi yang merendahkan vokal tinggi /i/ dan /u/ di suku kata akhir tertutup menjadi /e/ dan /o/; ia beroperasi untuk 'bukit' 
(/buket/) dan 'lanun' (/lanon/) tetapi tidak untuk 'aiskrim' (/aiskrim/) dan 'kasus' (/kasus/). Perkecualian ini dianggap bermasalah dan ia diatasi dengan mengaplikasikan peraturan preskriptif SB 'sebut sebagaimana yang dieja'.

Terdapat juga rasa bimbang akan timbulnya kekeliruan daripada kesepadanan huruf-fonem yang tidak sempurna itu. Namun, pada hakikatnya, tidak sukar bagi penutur asli SJR untuk menyebut perkataan-perkataan yang disebut di atas. Mereka tahu bagaimana untuk menyebut 'suka' dan 'bola', iaitu /sukə/ dan /bola/, biar tidak konsisten sekali pun penyebutan huruf 'a' antara dua perkataan tersebut. Mereka juga tidak perlu banyak berfikir untuk merendahkan vokal tinggi /i/ di posisi akhir suku kata tertutup kepada /e/ untuk 'bukit' (/buket/) tetapi mengekalkan ' $i$ ' untuk 'aiskrim' (/aiskrim/). Mereka juga akan menyebut 'lanun' sebagai /lanon/ dan 'kasus' sebagai /kasus/ tanpa merasakan ada yang tidak kena dengan penyebutan ' $u$ ' yang berbeza itu. Terdapat keseragaman yang tinggi di kalangan penutur SJR tentang cara kata-kata ini diucapkan.

Harus diingat bahawa SJR adalah model sebutan yang tabii yang dikawal oleh peraturan bahasa dalam minda penutur. Rumus-rumus fonologi yang dibangunkan ahli bahasa untuk mendeskripsikan tingkah laku penutur SJR itu mungkin masih belum sampai ke tahap yang benar-benar mewakili peraturan mental itu. Walau bagaimanapun, rumus-rumus yang sedia ada mampu menjelaskan sejumlah besar data fonetik termasuk huraian tentang tiga ciri yang membezakan SJR dan SB (Farid, 1980). Namun demikian, masih terdapat data seperti yang ditunjukkan di atas yang tidak dapat dijelaskan berdasarkan rumus-rumus tadi. Ini hanya mencerminkan kekerdilan manusia dalam usahanya menggali dan memahami rahsia alam (termasuk perilaku manusia berbahasa). Kesedaran ini penting agar SJR dihormati sebagai sistem sebutan yang tabii dengan segala 'kecacatan'nya. la harus terus dikaji bagi mendapatkan huraian yang lebih memuaskan daripada 'membetulkan'nya supaya menjadi 'sistematik dan konsisten'.

Kesarjanaan dalam bidang fonologi bahasa Melayu tidak semestinya memerlukan pemulihan. Perkecualian daripada rumus deskriptif tidak unik kepada bahasa Melayu. Sebagai contoh dalam bahasa Inggeris, terdapat banyak kata kerja yang tidak mengikut pola infleksi yang biasa, iaitu ada regular verbs (kata kerja biasa seperti: 'jump'-'jumped'; 'reel'-'reeled'; brew'-'brewed') dan ada irregular verbs (kata kerja tak biasa: 'buy'-'bought'; 'eat'-'ate'; 'throw'-'threw'). Namun demikian, kata kerja-kata kerja yang tidak biasa itu kekal sebagai sebahagian daripada bahasa Inggeris. Seharusnya juga begitu dengan bahasa Melayu; banyak perkataan yang sebutannya menyimpang daripada ketetapan yang sedia ada. Namun ini tidak harus dijadikan sebab untuk 'membetulkan' seluruh sistem sebutan.

\section{Sebutan Baku lebih mudah dipelajari dan diajar}

Seperti yang dibincangkan di atas, tidak sukar untuk penutur asli SJR mengucapkan kata-kata dalam bahasa Melayu walaupun perlu memadankan bunyi yang berbezabeza pada satu-satu huruf. Walau bagaimanapun, terdapat keprihatinan bahawa ketidaktekalan sebutan yang wujud dalam SJR menimbulkan kesulitan kepada anakanak kecil yang belajar membaca dalam bahasa Melayu (Pairah Satariman, 2007; 
Suratman, 1989) terutama mereka yang tidak terdedah kepada bahasa Melayu di rumah dan mempelajarinya hanya di sekolah.

Pada dasarnya, ini adalah isu pedagogi dan pembelajaran (Hulme, et al, 2012). Amalan umum untuk mengajar membaca dalam Bahasa Melayu adalah dengan menggunakan kaedah fonik - menyahkodkan perkataan suku kata demi suku kata. Pelajar diajar bahawa setiap konsonan dan vokal mempunyai satu nilai bunyi, misalnya, ' $r$ ' disebut /r/, 's' disebut /s/, dan 'a' disebut /a/. Menggabungkan setiap konsonan itu dengan 'a' menghasilkan suku kata /ra/ dan /sa/. Menyusun dua suku kata dalam satu rangkaian menghasilkan /rasa/, iaitu kata 'rasa'. Kaedah ini bermasalah jika kita mahu perkataan 'rasa' disebut /rasə/ seperti dalam SJR. Malangnya, bukan kaedah mengajar yang disemak semula dan pedagogi yang lebih sesuai dibangunkan demi membantu pelajar membaca 'rasa' sebagai /rasə/, sebaliknya sebutan itu yang dianggap bermasalah dan perlu dibetulkan.

Oleh itu, tidak hairanlah jika setelah 'membetulkan' sebutan, bahasa Melayu menjadi 'lebih mudah' untuk dibaca. Dalam satu kaji selidik seramai 300 pelajar Menengah 3 dan 76 orang guru Bahasa Melayu sekolah menengah, Pairah (2007) mendapati bahawa 88.3 peratus responden pelajar melaporkan bahawa SB membantu mereka dalam pembacaan dan pengejaan. Selain itu, 92.1 peratus responden guru percaya bahawa SB telah berjaya memudahkan pelajar membaca dan mengeja. Bagaimanapun, kajian tersebut tidak menimbangkan lenggok sebutan pelajar-pelajar itu. Tidak mengejutkan jika akhirnya mereka bercakap dengan bahasa Melayu yang kedengaran "berbeza daripada ibu bapa dan nenek moyang" mereka (menukil kata-kata seorang bapa Melayu yang mendengar anak perempuannya bercakap (Osman Sidek, 2013, dikutip daripada Yurni Irwati Mohamed Said, 2015)).

Sebenarnya, tanpa SB pun, bahasa Melayu jauh lebih mudah 'dibaca' (dalam ertikata membunyikan huruf) kerana ia mempunyai padanan huruf-fonem yang lebih telus, berbanding bahasa Inggeris. Jika sukar mengajar menyebut 'rasa' dalam SJR kerana huruf 'a' dalam suku kata pertama dan kedua mewakili dua fonem yang berbeza (/a/ dan /ə/), bayangkan betapa sukarnya mengajar huruf 'a' dalam bahasa Inggeris. Dalam bahasa Inggeris, 'a' mewakili bukan dua tetapi empat fonem: /æ/ ('man'), /a:/ ('can't'), /3:/ ('sofa') dan /ex/ ('ancient'); Begitu juga huruf 'c', ia mewakili empat fonem: /s/ ('city'), /k/ ('cotton'), /J/ ('species') dan /t// (cello); dan rangkaian fonem /^f / diwakili dalam ejaan sebagai 'uff' ('stuff') dan 'ough' ('enough'). Guru Bahasa Inggeris perlu bergelut dengan lebih banyak 'ketidaktekalan' sebutan dan yang lebih rumit tetapi mereka menerima bahasa itu seadanya dan merancang pengajaran sesuai dengan 'ketidaktekalan' itu. Pelajar masih dapat membaca dengan segala 'kecacatan' yang ada pada bahasa itu.

Dalam pengajaran membaca dalam bahasa Inggeris, huruf yang tidak dapat dinyahkodkan melalui fonik diajar dengan mengecam seluruh kata (whole word) atau pengecaman kata (word recognition). Melalui fonik, pelajar diajar bahawa huruf 'b' mewakili fonem /b/, seperti dalam 'bee' ('lebah'), 'bus' ('bas'), dan 'boot' ('kasut'). Gagasan fonik 'satu huruf satu bunyi' dilonggarkan bagi menampung fonem-fonem yang diwakili lebih daripada satu huruf atau rangkaian huruf seperti fonem /f/ yang diwakili huruf 'f', 'ff', 'gh' dan 'ph'. Hanya perkataan seperti 'once' ('sekali') dan 'cough' ('batuk') yang tidak mudah dinyahkodkan melalui fonik diajar menggunakan pendekatan seluruh kata. 
Dua pendekatan ini - fonik dengan penekanan pada perkaitan huruf dengan fonem, dan pengecaman kata dengan penekanan pada seluruh kata dan makna sering disepadukan dalam program membaca bahasa Inggeris (Asmah, 1993; Jones \& Deterding, 2007). Untuk bahasa Melayu, tiada keperluan mendesak untuk menggunakan kaedah pengecaman kata, hanya meluaskan kaedah fonik bagi menampung fonem-fonem yang diwakili lebih daripada satu huruf. Kanak-kanak yang belajar membaca harus diberitahu bahawa kebanyakan huruf dalam bahasa Melayu mewakili satu fonem tetapi terdapat beberapa huruf yang mewakili lebih daripada satu fonem (bergantung pada posisi huruf-huruf itu dalam perkataan).

\section{Sebutan dan Identiti Penutur Bahasa}

Seperti yang dinyatakan sebelum ini, berdasarkan tiga ciri yang membezakan sebutan-sebutan standard dalam bahasa Melayu, model SB serupa model sebutan standard Bahasa Indonesia (SBI) tetapi berbeza dengan model SJR. Kelainan /a/ terletak antara SJR dan SB dan SBI. Ini bermakna orang Melayu Singapura yang mengamalkan SB akan kedengaran seperti orang Indonesia di peringkat segmen bunyi. Sesungguhnya, bagi orang Melayu Singapura yang tidak setuju dengan dasar SB, masalahnya ialah SB menjadikan mereka kedengaran janggal.

Perhatikan petikan daripada rayuan Encik Guntor Sadali, mantan Editor Berita Harian (BH). Berucap di majlis makan malam Anugerah Berita Harian 2011, beliau dilaporkan telah mempersoalkan keperluan menggunakan SB (BH, 2011a):

"Setelah hampir dua dekad sebutan baku diperkenalkan di sekolah-sekolah, saya rasa sudah tiba masanya Majlis Bahasa Melayu Singapura meneliti semula dengan serius objektif langkah tersebut dan sama ada ia wajar diteruskan. ...

Sebutan bahasa Melayu Johor-Riau yang kini digunakan masyarakat Melayu Singapura seharusnya dapat diterima sebagai sebutan yang standard atau baku....

Anggota masyarakat Melayu pada umumnya mendapati sebutan baku begitu janggal, dan disebabkan itu mereka tidak menggunakannya dalam kehidupan harian mereka.

Malaysia, yang sama-sama memulakan usaha ini dengan Singapura, juga tidak lagi menggunakan Sebutan Baku dalam media penyiaran mereka.

Jadi, persoalannya ialah patutkah kita terus mengajar Sebutan Baku di sekolah?

Kepada saya, ia satu usaha yang sia-sia. ...

Marilah kita bercakap dengan cara yang membolehkan kata-kata keluar daripada lidah kita dengan mudah tanpa kedengaran kaku atau seperti dipaksa-paksa."

Encik Guntor bukan orang pertama yang menyuarakan keprihatinannya terhadap SB (rujuk Mohd Zulkifli Rahmat, 2003; Awalludin Ghani, 2007; dan lain-lain) tetapi kerana kedudukan beliau sebagai Editor BH, kenyataannya diberi lebih 
perhatian oleh masyarakat termasuk MBMS (BH, 2011b). Seperti yang dijangkakan, keraguannya terhadap penerusan dasar SB telah mencetuskan perbahasan bukan sahaja di akhbar arus perdana, tetapi di media sosial seperti Facebook, bahkan di majlis-majlis perkahwinan. Ini mendorong Encik Maarof Salleh, mantan Presiden Majlis Ugama Islam Singapura, dalam ulasannya di BH, mencadangkan: "selagi dasar atau peraturan adalah buatan manusia, ia wajar disemak dari masa ke masa, dipinda jika perlu, dan juga dirombak jika itulah yang diperlukan." (Maarof, 2011).

Sejak itu, terdengar suara-suara yang meminta supaya diadakan semakan atau yang mengkritik dasar SB (misalnya, Annaliza Bakri, 2013; Yurni Irwati, 2015). Dalam surat kepada akhbar The Sunday Times, seorang bapa Melayu berkongsi keprihatinannya tentang anak perempuannya yang kedengaran janggal apabila bercakap menggunakan SB, yang beliau rujuk sebagai 'Melayu Baku' (Osman, 2013, dikutip daripada Yurni Irwati, 2015: 62-63):

“Menguji 'Melayu Baku' sewaktu makan malam bersama keluarga, anak perempuan saya yang bersekolah kedengaran berbeza daripada saya, isteri saya, ibu bapa dan datuk nenek kami ...

Seperti orang Melayu dahulu, kami bercakap dengan sebutan yang dikenali sebagai 'Melayu Johor-Riau' ...

Walaupun saya dapat memahami apa yang anak perempuan saya katakan dalam 'Melayu Baku', ... persoalannya ialah mengapa sistem pendidikan kita mahu membuat bahasa Melayunya kedengaran berbeza daripada orang tua dan nenek moyangnya? Jika sebabnya adalah demi penyeragaman bahasa Melayu di rantau ini, nampaknya ia tidak logikal kerana usaha ini hanya dilakukan secara aktif di Singapura yang penduduk Melayunya kecil jumlahnya berbanding dunia berbahasa Melayu yang lebih luas.

Dunia Melayu yang lebih luas terus berbangga dengan warisan lisan mereka dan menghargai kepelbagaian sebutan dan loghat, serta slanga dan bahasa basahan sebagai sebahagian daripada warisan yang hidup dan dinamis.

Usaha 'Melayu Baku' Singapura mencerminkan obsesi untuk memudahkan warisan yang kompleks demi memudahkan pengajaran. Akhirnya, ini akan menyebabkan orang Melayu Singapura kehilangan warisan lisan mereka. Fikirkanlah semula dasar ini sebelum keadaan tidak dapat dipulihkan."

Pandangan bahawa teras kebudayaan Melayu Singapura berindekskan SJR $(\mathrm{BH}, 2017)$ sejalan dengan pendirian mahasiswa Melayu Singapura. Dalam kaji selidik 100 orang responden (berusia antara 18-25 tahun) dari enam buah universiti tempatan, Sakinah Mohd Mohsen (2019) mendapati bahawa 94 peratus responden melaporkan bahawa SJR (bukan SB) mewakili masyarakat Melayu Singapura. 91 peratus pula berpendapat bahawa SJR (bukan SB) lebih tepat mewakili bagaimana mereka sendiri berbahasa Melayu, dan 86 peratus responden lebih suka menggunakan SJR (bukan SB) ketika berkomunikasi dalam bahasa Melayu.

Perlu diingat bahawa di seberang tambak, isu identiti juga tergambar dalam keputusan Malaysia untuk menggugurkan SB pada tahun 2000. Prof Asmah Haji Omar dari Universiti Malaya dipetik sebagai berkata (Utusan Online, 2000b): 


\begin{abstract}
"Sistem sebutan baku bahasa Melayu yang diamalkan sejak tahun 1988 boleh melenyapkan identiti bahasa Melayu asal yang telah digunakan sejak zamanberzaman. ... Sebutan baku tidak melambangkan identiti kemelayuan ...

la tidak langsung mencerminkan bahasa Melayu yang dikenali mempunyai alunan lagu dan irama yang indah.

Bahasa baku bila digunakan (dengan SB) tidak kedengaran macam bahasa Melayu selain ia juga merupakan bahasa yang dibuat-buat dan intonasinya bila dituturkan agak kasar, ...

Sebutan baku tidak langsung melambangkan ketulenan bahasa Melayu JohorRiau yang modelnya telah digunakan sejak dahulu lagi."
\end{abstract}

\title{
Sebutan Hibrid
}

Tidak banyak kajian yang dilakukan untuk memahami kesan SB ke atas 'lidah' penutur bahasa Melayu. Dalam kajian oleh Sakinah (2019) yang dirujuk sebelum ini, beliau turut menganalisis secara fonetik ucapan spontan dan bacaan 10 respondennya. Dapatan menunjukkan bahawa SB yang mampu dituturkan adalah tidak sempurna walaupun responden telah diarah secara eksplisit supaya bercakap dan membaca dengan SB sebaik mungkin. Sebutan yang ditunjukkan oleh responden adalah sebutan hibrid, iaitu campuran SB dan SJR.

Dalam mengucapkan huruf 'a' dalam suku kata akhir terbuka ketika membaca senarai perkataan dan perenggan, ketepatan sebutan berpandukan SB adalah tinggi dan agak sama (purata 98.5\%). Ketekalan dalam menyuarakan huruf ' $r$ ' di akhir suku kata ketika membaca senarai perkataan dan perenggan juga sama tetapi rendah sedikit (purata 91.9\%). Mengucapkan 'i' dan 'u' dalam suku kata akhir tertutup, bagaimanapun, mencatat tahap ketepatan yang berbeza-beza. Ketika membaca senarai perkataan, responden dapat mengucapkan 'i' dan 'u' pada ketepatan $93.7 \%$ tetapi ketika membaca perenggan, ketepatan jatuh ke paras $76.2 \%$ oleh kerana penyebutan sesetengah responden beralih kepada SJR, iaitu menyebut ' $i$ ' dan ' $u$ ' sebagai /e/ dan /o/.

Ketepatan jatuh ke paras terendah dalam ucapan spontan yang mana ciri SJR lebih ketara. Ini mungkin kerana responden tidak mempunyai masa untuk mengawasi sebutan ketika bercakap berbeza ketika membaca. Ketepatan dalam mengucapkan 'a' dan menyuarakan ' $r$ ' dalam ucapan spontan mengikut SB turun ke paras sekitar $82 \%$. Ketika mengucapkan ' $i$ ' dan ' $u$ ', paras ketepatan menjunam kepada $26.7 \%$ dan $31.0 \%$. Ini bermakna apabila seseorang itu berkata beliau bercakap menggunakan SB, beliau sebenarnya mengamalkan sebutan hibrid, iaitu ciri SBnya terbatas kepada huruf ' $a$ ' dan ' $r$ ' manakala huruf ' $i$ ' dan ' $u$ ' bercirikan SJR, iaitu /e/ dan /o/.

Dapatan yang serupa diperolehi Maisarah (2019) dalam kajian beliau ke atas sebutan 20 orang responden yang terdiri daripada pemimpin pemerintah, pembaca berita di televisyen, pembaca berita di radio, dan juruhebah di radio. Antara empat kumpulan ini, pembaca berita di televisyen agak tekal sebutan SBnya (ketepatan menyebut huruf ' $a$ ' dalam suku kata akhir terbuka dan menyuarakan huruf ' $r$ ' di akhir suku kata agak sama - purata 98.2\%; ketepatan menyebut huruf ' $u$ ' dan ' $i$ ' di 
suku kata akhir tertutup masing-masing $86.2 \%$ dan 61.9\%) manakala tiga kumpulan yang lain jelas mengamalkan sebutan hibrid (ketepatan menyebut huruf 'a' sekitar 83.6\%; huruf ' $r$ ' sekitar 59.8\%; dan huruf ' $i$ ' dan ' $u$ ' di paras terendah - sekitar 41.2\%). Kajian juga menunjukkan bahawa SB bukan sahaja cuba digunakan (dengan sebutan hibrid) dalam konteks formal (ucapan di parlimen dan laporan berita) tetapi penggunaannya telah memasuki domain yang tidak formal juga (perbualan juruhebah di radio sesama sendiri dan bersama pemanggil). Ini bercanggah dengan dasar yang memperuntukkan SB kepada situasi formal sahaja.

Dapatan-dapatan ini menunjukkan tanda-tanda bahawa model sebutan yang diharapkan pemerintah dan MBMS belum kesampaian. Setelah 25 tahun melaksanakan dasar SB, model sebutan yang mampu dicapai oleh pemimpin, pembaca berita, mahasiswa dan mungkin juga golongan pelajar yang lain adalah model sebutan yang bercampur aduk. Jika trend ini menjadi kebiasaan dan dasar SB diteruskan di sekolah, Singapura mungkin akan melahirkan masyarakat Melayu yang kian tersisih daripada identiti asalnya. Mereka tidak dapat bertutur dalam bahasa Melayu menggunakan SB sebagaimana yang diharapkan pada masa yang sama loghat SJR mereka tidak lagi sempurna. Hal ini umpama peribahasa 'yang dikejar tak dapat, yang dikendong berciciran'.

Pada awal pelaksanaan SB, tiada penutur asli SB. Pembaca berita dan guruguru bahasa Melayu antara golongan yang diberi latihan menggunakan SB (Mohamed Pitchay Gani, 2004; Suratman, 1987). Lebih mudah untuk menggunakan SB jika tugas seseorang hanya memerlukannya membaca daripada skrip. Namun demikian, pemimpin dan pembaca berita di radio juga membaca daripada skrip tetapi mereka hanya dapat mencapai tahap sebutan hibrid (Maisarah, 2019). Apatah lagi guru bahasa Melayu yang tidak dapat bergantung pada skrip ketika mengajar. Tuntutan ke atas mereka lebih tinggi - mengawasi sebutan dan juga berfikir dan menyampaikan isi pengajaran secara spontan. Besar kemungkinan ciri SB yang mampu dikawal oleh guru ialah ' $a$ ' dan ' $r$ ' manakala 'i' dan ' $u$ ' kekal bercirikan SJR. Ini mungkin model SB yang dicontohi murid dan kesannya dapat dilihat dalam ucapan mahasiswa (Sakinah, 2019).

\section{Kesimpulan}

Makalah ini menyumbang kepada wacana penstandardan bahasa dengan meneliti evolusi bahasa standard dan sebutan standard, khususnya Bahasa Melayu Standard (BMS), Sebutan Johor-Riau (SJR atau kelainan /ə/) serta kelainan /a/, dalam konteks sosio-sejarah masyarakat Melayu Singapura dan Malaysia. BMS dan SJR adalah kelainan bahasa dan sebutan yang tabii yang berkembang secara kebetulan daripada dialek daerah kepada dialek supralokal. Kelainan /a/ pula sebutan standard yang terbatas kepada orang Melayu di utara Semenanjung dan Malaysia Timur, yang mampu beralih kepada SJR jika perlu. Selain itu, SJR sebati dengan orang Melayu Singapura dan Malaysia, mendarah daging dalam jiwa mereka buat sekian lama. Dalam kalangan orang Melayu Singapura yang berumur 35 tahun ke atas yang bersekolah sebelum SB diperkenalkan, SJR adalah sebutan harian mereka baik ketika berbual dalam situasi yang santai (BMB) mahupun yang formal (BMS). Pembakuan 
sebutan melalui SB merupakan penafian kewujudan variasi sosial dalam amalan penutur bahasa Melayu (Idris Aman \& Shahidi Abd. Hamid, 2001).

Tiada sifat intrinsik dalam mana-mana bahasa dan sebutan yang tabii yang melayakkannya dipilih menjadi asas kepada bahasa dan sebutan yang standard atau baku. Makalah ini menegaskan pembakuan BMB dan SJR atas faktor-faktor ekstrinsik - media cetak dan media penyiaran yang berputik di Singapura yang berdialekkan Johor-Riau, yang secara tidak langsung memantapkan penggunaan BMS dan SJR serta meluaskan jumlah penuturnya di Malaysia dan Singapura. Bukan sedikit peranan orang Melayu Singapura dahulu dalam menjadikan SJR sebutan standard bahasa Melayu yang ulung. Oleh itu, Singapura harus berasa bangga dan meraikan peranan penting yang mereka mainkan. SJR adalah warisan yang berharga yang kini kembali diiktiraf di Malaysia. Malangnya, Singapura terus meminggirkannya atas pertimbangan yang boleh dipertikaikan.

Makalah ini turut menilai semula kebakuan Sebutan Baku (SB) yang merupakan sebutan yang dibuat-buat yang diangkat melalui perundangan sebagai sebutan yang standard. Sukar mempertahankan SB yang berpandukan prinsip "katakata diucapkan sebagaimana yang dieja' selagi ejaan bahasa Melayu tidak menepati sebutan. Dalam wacana tentang SB, ada yang menyamakan kelainan /a/ yang tabii dengan SB yang tidak. Prof Asmah Haji Omar, ketika menyokong keputusan jemaah menteri Malaysia untuk memansuhkan SB, menyifatkan SB sebagai sebutan yang "dibuat-buat", mempunyai intonasi yang "agak kasar" dan "tidak melambangkan identiti kemelayuan" (Utusan Online, 2000b). Beliau, yang sendiri berasal dari utara Semenanjung dan bangga dengan dialeknya, tidak mungkin merujuk kepada kelainan /a/ dalam kenyataannya itu. Hanya SB yang tiada penutur asli di Malaysia mahupun di Singapura mempunyai sifat-sifat itu.

\section{Nota Akhir}

1. Terdapat dialek sosial yang ketiga, bahasa pasar, yang pernah menjadi lingua franca di Singapura. la jarang lagi kedengaran sejak bahasa Inggeris mengambil alih sebagai bahasa penyatu kaum di Singapura melalui dasar yang mengutamakan bahasa Inggeris.

2. Aksara IPA (International Phonetic Association, 1999) digunakan untuk mewakili bunyi. Lambang yang diletakkan dalam kurungan mereng (/ /) mewakili bunyi (fonem) dan dalam kurungan berkotak ([ ]) mewakili variasi fonem (alofon). Lambang dalam pengikat kata (' ') mewakili huruf. Misalnya, huruf ' $k$ ' dalam bahasa Melayu mewakili dua fonem, /k/ dan / ?/, bergantung pada posisinya dalam suku kata ('kakak' / kaka?/). Huruf 'e' juga mewakili dua bunyi dalam bahasa Melayu, /e/ dan /ə/ ('enak' /ena?/; 'emak' (/əma?/). /j/ merupakan lambang IPA untuk huruf ' $y$ ' seperti dalam 'yuran' (/juran/). Fonem ini diselitkan antara /i/ dan /a/ dalam 'tepian' (/təpijan/).

3. Bagaimanapun, SB masih dibenarkan untuk tujuan pengajaran dan pembelajaran bahasa Melayu di sekolah-sekolah di Malaysia. Namun, para pelajar tidak diwajibkan menggunakannya dalam ujian lisan.

4. Terdapat satu lagi perbezaan antara kelainan /ə/ dan kelainan /a/ yang tidak ditunjukkan di sini. Dalam kelainan /ə/, huruf 'e' dan 'o' diucapkan sebagai vokal separuh tinggi, iaitu /e/ dan /o/, tetapi dalam kelainan /a/, ia disebut sebagai vokal separuh rendah, iaitu, / $\varepsilon /$ dan /\%/. Oleh itu, perkataan seperti 'elak', 'petak', 'orang' dan 'tolak' masing-masing 
disebut sebagai /ela?/, /peta?/, /oran/ dan /tola?/ dalam kelainan /ə/ tetapi sebagai /عla?/, /peta?/, /oray/dan /tola?/ dalam kelainan /a/ (Asmah, 1992b).

5. Harus diingat bahawa bahasa Indonesia akan tetap kedengaran berbeza daripada bahasa Melayu walaupun mengongsi tiga ciri yang sama melibatkan huruf-huruf ' $a$ ', ' $r$ ', ' $i$ ' dan ' $u$ ' itu. Hal ini demikian kerana terdapat ciri-ciri fonetik lain yang berbeza antara dua sebutan ini. Selain itu, kosa kata, ejaan, morfologi dan intonasi antara dua bahasa ini juga berbeza.

\section{Rujukan}

Alisjahbana, S. T. (1976). Language planning for modernization: The case of Indonesian and Malaysian (Jilid 14). The Hague: de Gruyter Mouton.

Amat Juhari Moain (1996). Perancangan bahasa: Sejarah aksara Jawi. Kuala Lumpur: Dewan Bahasa dan Pustaka.

Annaliza Binte Bakri (2013). The vision of Arif Budiman: A case study of Malay language education in Singapore. Tesis MA, Jabatan Pengajian Melayu, Universiti Nasional Singapura.

Asmah Haji Omar (1986). Sociolinguistic varieties of Malay. Dlm. A. Fishman, A. Tabouret-Keller, M. Clyne, B. Krishnamurti \& M. Abdulaziz (Penyusun), The Fergusonian Impact, Vol. 2: Sociolinguistics and the Sociology of Language (hlm. 191-206). Berlin, New York: Mouton de Gruyter.

Asmah Haji Omar (1988). Susur Galur Bahasa Melayu. Kuala Lumpur: Dewan Bahasa dan Pustaka.

Asmah Haji Omar (1992a). The Linguistic Scenery in Malaysia. Kuala Lumpur: Dewan Bahasa dan Pustaka.

Asmah Haji Omar (1992b). Kajian dan Perkembangan Bahasa Melayu. Kuala Lumpur: Dewan Bahasa dan Pustaka.

Asmah Haji Omar (1993). Essays on Malaysian Linguistics. Kuala Lumpur: Dewan Bahasa dan Pustaka.

Asmah Haji Omar (2005). Alam dan Penyebaran Bahasa Melayu. Kuala Lumpur: Dewan Bahasa dan Pustaka.

Asmah Haji Omar (2008). Nahu Kemas Kini: Panduan bahasa yang baik dan betul. Kuala Lumpur: PTS Professional.

Asraf (1984). Sebutan Baku Bahasa Melayu Berdasarkan Prinsip Fonemik. DIm Awang Sariyan (Penyusun), Prosiding Kongres Bahasa dan Persuratan Melayu IV (hlm. 611-623). Kuala Lumpur: Dewan Bahasa dan Pustaka.

Awalludin Ghani (2007). Sebutan baku mungkin kurang sesuai di sini. Berita Harian, 1 Disember 2007, hlm.30.

Awang Sariyan (2000). Warna dan Suasana: Perancangan Bahasa Melayu di Malaysia. Kuala Lumpur: Dewan Bahasa dan Pustaka.

Benjamin, G. (1993). Grammar and polity: The cultural and political background to Standard Malay. DIm. W. A. Foley (Penyusun), The role of theory in language description (hlm. 341-360). The Hague: Mouton de Gruyter.

Berita Harian (2004, Mac 19). Sebutan baku bantu murid Melayu, hlm. 8.

Berita Harian (2011, Julai 14). Editor BH saran disemak dasar penggunaan sebutan baku, hlm. '1.

Berita Harian (2011b, Julai 15). Kenyataan Majlis Bahasa Melayu Singapura, hlm.2. 
Berita Harian (2017, September 4). Pensyarah: budaya tali pengikat bangsa, hlm.4.

Berita Minggu (2018, Februari 25). Sidek teruja pemimpin generasi baru ambil langkah segar bangunkan bahasa, hlm.14.

Collins, J. T. (1998). Malay, world Language: A short history. Kuala Lumpur: Dewan Bahasa dan Pustaka.

Coupland, N. (2014). Sociolinguistic change, vernacularization and broadcast British media. Mediatization and Sociolinguistic Change, 2, 67-96.

Farid M. Onn (1980). Aspects of Malay phonology and morphology: A generative approach. Bangi, Malaysia: Universiti Kebangsaan Malaysia.

Curriculum Planning \& Development Division, MOE (1990). Laporan Pelaksanaan Sebutan Baku di Sekolah-sekolah. Singapura: MOE.

Hashim Musa (2006). Epigrafi Melayu, sejarah sistem tulisan dalam bahasa Melayu. Kuala Lumpur: Dewan Bahasa dan Pustaka.

Heng, D. (2011). Situating Temasik within the larger regional context: Maritime Asia and Malay State formation in the pre-modern era. DIm. D. Heng \& Syed Muhd Khairudin Aljunied (Penyusun), Singapore in Global History (hlm. 4647). Amsterdam: Amsterdam University Press.

Hjarvard, S. (2004). The Globalization of Language: How the Media Contribute to the Spread of English and the Emergence of Medialects. Nordicom Review, 25(12), 75-98.

Hulme, C., Bowyer-Crane, C., Carroll, J. M., Duff, F. J., \& Snowling, M. J. (2012). The causal role of phoneme awareness and letter-sound knowledge in learning to read: Combining intervention studies with mediation analyses. Psychological Science, 23(6), 572-577.

Idris Aman \& Shahidi Abd. Hamid (2001). Variasi Sosial Sebutan Bahasa Melayu: Kajian sosiofonologi di sekolah. Jurnal Bahasa, 1(4), 466-482.

Ismail Dahaman (1994). Pedoman Sebutan Baku Bahasa Melayu. Kuala Lumpur: Dewan Bahasa dan Pustaka.

International Phonetic Association (1999). Handbook of the International Phonetic Association: A guide to the use of the International Phonetic Alphabet. Cambridge University Press.

Jones, S. A. \& Deterding, D. (2007). Phonics and beginning reading: A practical guide for teachers in Southeast Asia. Singapore: McGraw-Hill Education.

Koh, A. S. (1990). Topics in Colloquial Malay. Tesis PhD. Universiti Melbourne.

Lippi-Green, R. (1997). Language, ideology, and discrimination in the United States. London: Routledge.

Maarof Salleh (2011). Meminda aturan bikinan manusia, Berita Harian, 5 Ogos 2011, hlm.18.

Maisarah Zulkifly (2019). Antara yang 'Baku' dan yang Biasa: Sebuah kajian fonetik sebutan bahasa Melayu Singapura. Latihan IImiah BA, Institut Pendidikan Nasional, Universiti Teknologi Nanyang, Singapura.

Milroy, J. \& Milroy, L. (2012). Authority in Language: Investigating Standard English. London: Routledge.

Mohamed Pitchay Gani Mohamed Abdul Aziz (2004). Laporan Khas Perlaksanaan dan Perkembangan Sebutan Baku di Singapura 1990-2003. Sekata 2004: 9-26. 
Mohd Zulkifli Rahmat (2003, Julai 17). Macam tak ada kerja, cari kerja. Berita Harian, hlm. 7.

Muhd Ariff Ahmad (1993). Pengalaman pembakuan bahasa (Melayu): Di [Indonesia, Malaysia dan] Singapura. Pesan: Kumpulan makalah sempena Bulan Bahasa 1993 (hlm. 29-42). Singapura: Jawatankuasa Bulan Bahasa.

Osman Sidek (2013, Februari 27). Review teaching of Malay pronunciation in schools. The Straits Times.

Pairah Satariman (2007). Kurikulum Bahasa Melayu Peringkat Sekolah Menengah di Singapura: Satu Penilaian Terhadap Pembentukan dan Pelaksanaannya. Tesis MA. Jabatan Pengajian Melayu, Universiti Nasional Singapura.

Pike, K. L. (1947). Phonemics: A technique for reducing languages to writing. Ann Arbor: The University of Michigan Press.

Rusdi Abdullah (2016). Kamus Kata: Bahasa Melayu Malaysia - Bahasa Indonesia. Bangi: Penerbit Universiti Kebangsaan.

Sakinah Mohd Mohsen (2019). "Sebutan Baku" as Perceived and Practiced by University Undergraduates. Laporan kajian URECA. Institut Pendidikan Nasional, Universiti Teknologi Nanyang, Singapura.

Suratman Markasan (1987). Perlukah kita mempunyai bahasa Melayu baku dan bilakah bahasa Melayu harus menjadi bahasa baku? Sekata, 4(1), 5-15.

Suratman Markasan (1989). Sebutan Baku Satu daripada Aspek Bahasa Baku. Kertas kerja yang dibentangkan di Sekolah Menengah Riverside, 1989.

The Straits Times (1993). Use bahasa baku, PM urges Malays. 30 Julai 2003, hlm.30.

Utusan Online (2000a). Sebutan baku dimansuh - Kementerian Pendidikan akan mansuhkan penggunaan bahasa baku. 26 Januari 2000. Diambil semula daripada https://mohdisa-abdrazak.blogspot.com/2010/01/kementerian-pen didikan-akan-mansuhkan.html

Utusan Online (2000b). Bahasa baku lenyapkan identiti bahasa Melayu. 26 Januari 2000. Diambil semula daripada https://mohdisa-abdrazak.blogspot.com/ 2010/01/sebutan-baku-lenyapkan-identiti-bahasa.html

Winstedt, R. O. (1992). A history of Johore, 1365-1895 (M.B.R.A.S. Reprints, 6.). Kuala Lumpur: Malaysian Branch of the Royal Asiatic Society.

Yurni Irwati Mohamed Said (2015). Singapore's bilingual policy: The ideological construction of the Singapore Malay identity in the globalized word. Tesis $\mathrm{PhD}$, Jabatan Bahasa dan Sastera Inggeris, Universiti Nasional Singapura. 